\title{
Inequality in developing economies: the role of institutional development
}

\author{
Adalgiso Amendola $\cdot$ Joshy Easaw $\cdot$ Antonio Savoia
}

Received: 27 March 2010 / Accepted: 12 July 2011

(C) Springer Science+Business Media, LLC 2011

\begin{abstract}
This paper studies the distributive impact of institutional change in developing countries. In such economies, property rights systems may preserve the interests of an influential minority, who can control key-markets, access to assets and investment opportunities, especially if they enjoy disproportionate political power. We test this hypothesis using cross-section and panel data methods on a sample of low- and middle-income economies from Africa, Asia and Latin America. Results suggest that: (a) increasing property rights protection increases income inequality; (b) this effect is larger in low-democracy environments; (c) some countries have developed political institutions capable of counterbalancing this effect.
\end{abstract}

Keywords Inequality · Developing economies $\cdot$ Institutions $\cdot$ Property rights $\cdot$ Democracy

JEL Classification $\mathrm{O} 15 \cdot \mathrm{O} 17 \cdot \mathrm{D} 70$

\section{Introduction}

The distribution of resources and the rules that govern them are central to economic development. In developing economies, economic performance reflects institutional arrangements

In the present paper we outline the main issues, provide and discuss the key empirical results. An extensive discussion of the issues raised in this paper (which also includes a survey of the recent theoretical and empirical literature), together with the complete empirical results are found in Amendola et al. (2011), this is the discussion paper version of this article: http://ideas.repec.org/p/exe/wpaper/ 1107.html.

A. Amendola

DISES, Universitá di Salerno, Via Ponte Don Melillo, 84084, Fisciano (SA), Italy

J. Easaw

Economics Department, University of Wales Swansea, Singleton Park, Swansea, SA2 8PP, UK

A. Savoia $(\varangle)$

Business School, Dept. Economics, University of Exeter, Streatham Court, Rennes Drive, Exeter, EX4 4PU, UK

e-mail: A.Savoia@exeter.ac.uk 
(established in colonial times and inherited by postcolonial states) which are ill-suited for development. According to Acemoglu et al. (2005), economic and political institutions are the primary cause of economic backwardness. Similarly, Besley and Ghatak (2010) emphasize the importance of property rights. Having concentrated mainly on the effects on national income, this debate leaves substantial room for an analysis of the distributional effects of institutions, especially the role of property rights protection.

Institutions governing economic and political processes affect personal incomes as they mould individual incentives and constrain the range of activities they can undertake. Such institutions include the rules that shape property rights protection, i.e., formal and informal rules that define and protect private property, and enhance the ability to appropriate returns from ownership and use of production factors. This paper uses both cross-section and panel data methods to test the hypothesis that property rights institutions exacerbate income inequality in developing countries, as they are conceived to preserve or promote the interests of the political and economic elite. In addition, unlike previous literature, we consider the interaction between political and economic institutions. Economic institutions enable narrower or broader property rights protection, depending on how inclusive the political system is. One channel is the regulation of entry into markets. In oligarchic societies, the dominant economic elite has enough political power to control key-markets by erecting entry barriers (e.g., through direct regulation, but also obtaining subsidized credit or inputs), as well as protecting themselves from expropriation and redistributive taxation, thus granting themselves better opportunities to benefit from the ownership of production factors (see Acemoglu 2008). A second channel concerns wage-setting policies, as democracies increase the wages share through reforms of labor market institutions (see Rodrik 1999; and Robinson 2001). While economic institutions in oligarchic societies provide limited property rights protection to certain social groups and worsen distributional outcomes, this may be reversed when countries democratize. There are two inherent characteristics of democracy that enable it to modify the functioning of property rights institutions: political representation, through competing political parties, and participation, through voting. Both enhance the capability of low-income groups to organize and force the elite to reform institutions. Changed property relations enable the less well-off social groups to appropriate a higher income from the production factors they own. Hence, the distributional effect of property rights institutions could depend on the nature of the political system.

This is apparent when comparing Figs. 1 and 2, which plot the 1991-2000 average of the Gini index against the 1980-1990 average Fraser index of property rights protection (the horizontal and vertical line are their respective averages, 45.52 and 4.11). Figure 1 shows a moderate, positive correlation (with an estimated coefficient of $1.621, t$-ratio $=2.02, R^{2}=$ $0.061,47$ countries). However, when splitting the sample according to the mean (5.44) of the 1960-1990 average of Vanhanen's democracy index, Fig. 2 shows that the regression slope can be quite pronounced in countries below the democracy average (dots), while it becomes negative in countries scoring above such value (squares), suggesting that the relationship between income inequality and the protection of private property in developing economies could be a nonlinear one.

Empirical research has looked at the broader cross-country context, rather than at developing economies, and has tended to treat institutions as an indistinct body so far, while we attempt to disentangle the distributional impact of political and economic institutions. ${ }^{1}$ The paper provides novel evidence on the role of property rights institutions, whose effect may

\footnotetext{
${ }^{1}$ See Chong and Calderón (2000), Chong and Gradstein (2007), Scully (2002), Carter (2006), Berggren (1999).
} 


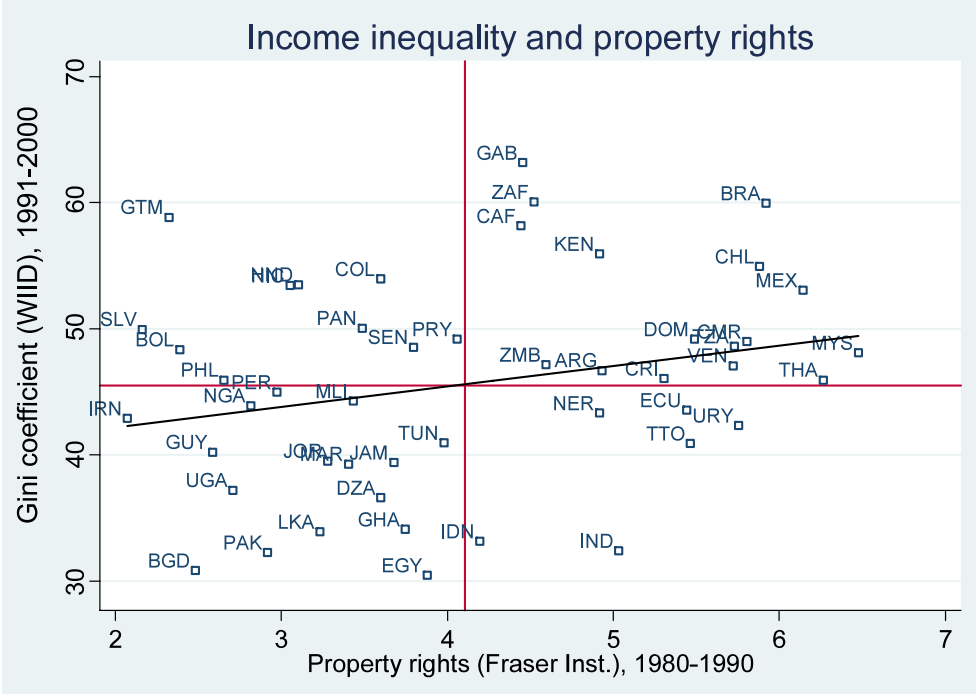

Fig. 1 Inequality and property rights in developing economies

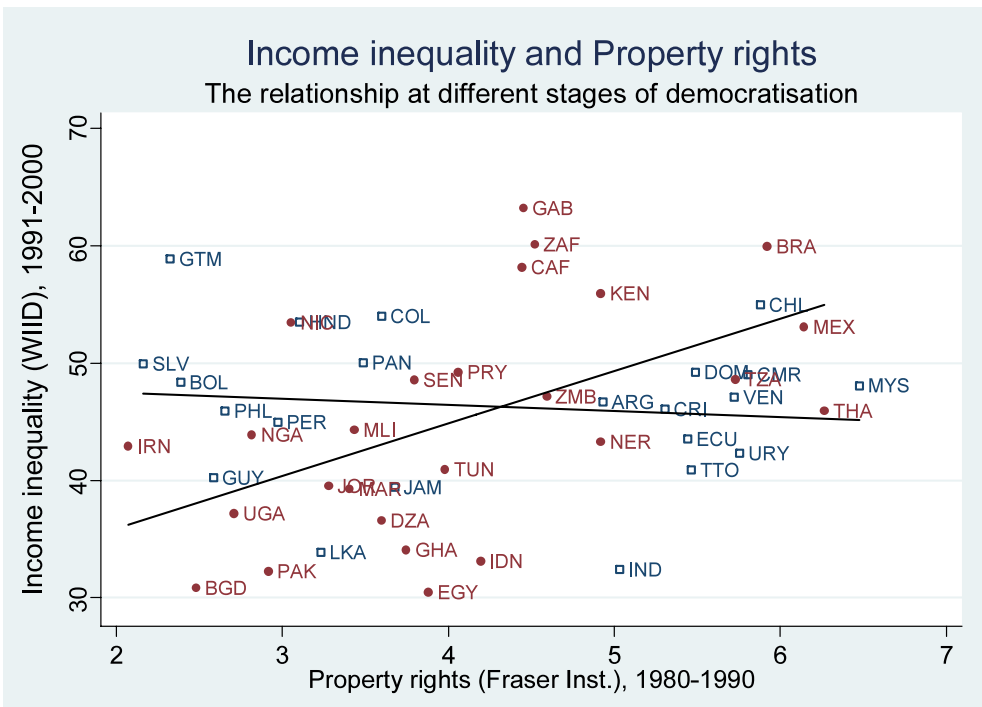

Fig. 2 Inequality and property rights at different stages of democratization

depend on the type of political institutions, but also on the relationship between political systems and economic inequality, moving beyond the standard argument that democracy may increase redistributive expenditure (see Gradstein and Milanovic 2004). In policy terms, filling this gap is useful to understand the effect of reforms aimed at creating investment incentives or extending economic opportunities for low-income groups (e.g., access to and control of production factors). 
The paper is structured as follows: Sect. 2 formulates the econometric approach and also introduces the data used; and Sect. 3 presents the results. The final section summarizes and speculates on the implications of this empirical analysis.

\section{Econometric methods and data}

Above it was argued that the effect of property rights institutions on recent levels of income inequality should vary with democratization. Let us now turn to the econometric strategy and the data used to test this hypothesis.

\subsection{Econometric methods}

Regressions based on cross-section averages are a suitable approach to test relationships, as in this case, whose mechanisms have long-run characteristics (e.g., rooted in colonial or post-colonial history) and evolve slowly over time. ${ }^{2}$ Hence, the benchmark OLS regression takes the form:

$$
\operatorname{Ineq}_{i, T, T-1}=\beta_{0}+\beta_{1} \cdot I_{i, t, t-1}+\beta_{2} \cdot Q_{i, t, t-1}+X_{i, t, t-1}^{\prime} \cdot \varphi+\varepsilon_{i, t, t-1}
$$

where, Ine $q_{i, T, T-1}$ is the average inequality index of interest for country $i$ between the end of the sample period, $T$, and $T-1$. $Q_{i, t, t-1}$ is a measure of economic institutions, i.e., degree of property rights protection, averaged between times $t$ and $t-1$, with $t<T-1$. Such choice of period attenuates problems of reverse causality that might cloud its estimated effect $\beta_{2}$, which can be interpreted as the long-run effect of property rights on income inequality. Similarly, the level of democratization is $I_{i, t, t-1}$, while $X_{i, t, t-1}$ is a set of controls. Following Li et al. (1998), it includes education, land inequality and the level of financial development. ${ }^{3}$ We also control for regional dummies, to capture unobserved regional effects, and for other long-run determinants of inequality, which include a measure of the level of economic development, to capture economy-size effects, and its square, to capture Kuznets curve-type effects. In addition, we condition on the suitability of land for wheat versus sugarcane, which, as proposed by Easterly (2007), is exogenous and picks the historical variation of inequality. Finally, $\varepsilon_{i, t, t-1}$ is the error, capturing all other omitted factors.

Equation (1) must be extended to a functional form allowing for interaction effects:

$$
\begin{aligned}
\text { Ineq }_{i, T, T-1}= & \beta_{0}+\beta_{1} \cdot I_{i, t, t-1}+\beta_{2} \cdot Q_{i, t, t-1}+\beta_{3} \cdot\left(Q_{i, t, t-1} \cdot I_{i, t, t-1}\right) \\
& +X_{i, t, t-1}^{\prime} \cdot \varphi+\varepsilon_{i, t, t-1} .
\end{aligned}
$$

Equation (2) implies that the partial effect of property rights institutions is now conditional on democratic consolidation: $\partial$ Ineq $/ \partial Q=\beta_{2}+\beta_{3} \cdot I_{i, t, t-1}$. In particular, $\beta_{2}$ becomes the impact of one unit change in property rights institutions on income inequality when democracy is zero. We expect that stronger property rights protection increases income inequality,

\footnotetext{
${ }^{2}$ Research that follow this strategy are Easterly (2007), and Chong and Calderón (2000), and Daudey and Garcia-Peñalosa (2007).

${ }^{3}$ The average level of education provides a greater supply of skilled labor, which tends to reduce the skill premium and hence reduces inequality in the distribution of labor incomes. Land inequality and the level of financial development capture the inequality of assets: how difficult it is to access credit for the poor, who lack collateral.
} 
i.e., $\beta_{2}$ is positive. Such effect is moderated by increased democratization, as this process modifies the functioning of property rights; therefore, $\beta_{3}$ is expected to take a negative sign. For a full interpretation of the partial effects, we have to consider the cases when democracy is not zero and then recalculate magnitude, standard errors and significance of the estimated effect.

Consistently with the attempt to explain long-run phenomena, the above cross-section approach would enable us to tell which countries adopt inequitable economic institutions based on political choices rooted in history. The potential consequence of averaging the variables over years is that it tends to obscure episodes of political and institutional change within countries, which should be reflected in a subsequent change in the distribution of resources. For example, such an approach does not capture the likely effects of episodes of political reforms toward democratization over time or, vice versa, of reversions to authoritarianism (e.g., some Latin American nations). If this is the case, one could complement the evidence from regressions based on cross-section averages with a panel approach concentrating on the within variation. A causal link between property rights and inequality suggests that we should also see a relationship between changes in property rights and changes in income inequality. Put differently, does income concentration (with its other characteristics held constant) become higher when its legal system increases private property protection? To answer this question, one has to investigate whether the cross-sectional relationship between the variables of interest disappears when country-fixed effects are included in the regression, thus removing the long-run determinants of both property rights protection and inequality that are time-invariant. This requires exploiting a fixed effects (FE) estimator, which is entirely based on time-series variation (e.g., as captured by deviations from individual means, within estimator). Furthermore, we can minimize the confounding effect of omitted variables by controlling for common trends, e.g., the decades since the late 1970s have witnessed world-wide economic and political shocks. Consequently, we recast the cross-section model in a panel context:

$$
\begin{aligned}
\text { Ineq }_{i t}= & \beta_{0}+\varphi \cdot \text { Ineq }_{i t-1}+\beta_{1} \cdot I_{i t}+\beta_{2} \cdot Q_{i t}+\beta_{3}\left(Q_{i t} \cdot I_{i t}\right) \\
& +\sum_{n=1}^{k} \varphi_{n} \cdot X_{i t, n}+\mu_{i}+\lambda_{t}+\omega_{i t} .
\end{aligned}
$$

Equation (3) incorporates country fixed effects, $\mu_{i}$, time-specific effects, $\lambda_{t}$, and an error term $\omega_{i t}$. But it also introduces a lag of the dependent variable. Income inequality, in fact, evolves slowly over time (see $\mathrm{Li}$ et al. 1998). It is a persistent phenomenon, which one has to control for. Therefore, a panel data approach requires a further refinement, as FE estimates of $\varphi$ would be, by construction, correlated with the error term and downward biased. This bias would be transmitted to the remaining variables, to the extent that they are correlated to it, thus inducing distortion in the other coefficients, including (overestimation or underestimation of) the impact of institutions (depending on the direction of correlation).

Since we have a small- $T$-large- $N$ panel, the size of this bias will not be negligible (as $T$ increases, FE estimator is consistent). This problem can usually be handled using generalized method of moments estimation. In a panel context, lagged values of the endogenous variables are valid instruments, as long as there is no (2nd order) serial correlation in the disturbances. However, such procedures are data intensive and require a fairly large number of consecutive observations: a standard that inequality, and property rights, data does not accommodate. Assuming that the instruments are relevant and valid, the resulting loss of 
degrees of freedom would be large when exploiting lags to use the available moment conditions. We are constrained by the sample size instead. The average $T$ is smaller than three for both inequality and property rights.

Notwithstanding, a dynamic approach is still feasible. Several suggestions have been proposed to correct for the bias of the FE estimator (see Baltagi 2008, pp. 147-148). In particular, Bruno (2005) extends previous results on bias approximation for finite samples by Bun and Kiviet (2003) to unbalanced panels. In its essence, this approach first suggests an expression to measure the FE bias and considers three possible nested approximations of the bias. We correct for the most accurate one. ${ }^{4}$ This results in least squares dummy variable corrected estimates (LSDVC), initialized by consistent estimates for dynamic models, with a Anderson and Hsiao (1982) estimator (with instrument in levels), which subtract the bias adjustments for each coefficient from FE estimates and apply bootstrapping to calculate the standard errors of the adjusted coefficients.

Exploiting a FE approach in this context does not come without costs. Data behavior in developing economies is such that, while property rights and democracy show enough variability over time (they exhibit similar standard deviations across and within countries), inequality tends to change significantly across countries, but little over time (see Amendola et al. 2011). Hence, methods that remove the effects of time invariant factors also remove most of the variation that one wishes to explain.

\subsection{Data}

This study uses aggregate data at country level. The sample is composed of 62 developing countries (excluding transition economies), defined as low- and middle-income economies in South and Central America, sub-Saharan Africa, North Africa and the Middle East and Asia. A full description and discussion of the data used is found in Amendola et al. (2011).

Income inequality, the dependent variable, is measured by the Gini coefficient of disposable household income, obtained from the World Income Inequality Database (WIID) (UNU-WIDER 2007). To address the well-known comparability problems arising when using cross-national databases of income inequality, we selected the top three quality rankings and adjusted such observations to maximize their comparability over time, within each country, as consistency of the time dimension is crucial in fixed effects panel methods.

We formed a series for each country by keeping the observations from the same source and survey, which represented the majority of observations for the country. In this way, we are confident that known and unknown methodological differences are potentially accounted for. However, this also means discarding a great deal of information, thus obtaining few data points for most developing economies. Therefore, each selected series was supplemented with observations originating from other surveys (rather than the survey with the majority of observations), where at the very least income definition and the income sharing unit are equivalent, and the area and population coverage are most extensive. ${ }^{5}$

This procedure still leaves us with the problem that observations are not comparable across countries. Hence, the final step is to normalize each observation using correction factors from a regression against dummies for gross income and earnings, expenditure and consumption, and using person as a reference unit (they are $7.15,-3.68,-1.27,3.87$ and

\footnotetext{
${ }^{4}$ This is $B_{3}=c_{1}\left(T^{-1}\right)+c_{2}\left(N^{-1} T^{-1}\right)+c_{3}\left(N^{-1} T^{-2}\right)$, where $c_{1}, c_{2}$ and $c_{3}$ are parameters estimated via Monte Carlo simulations.

${ }^{5}$ We followed an initial suggestion from Luis Angeles, to whom we are grateful.
} 
-0.37 , respectively), so to obtain estimates of the Gini index based on disposable household income.

Our preferred measure of protection of private property rights is extracted from the Fraser Economic Freedom index. In its recent denomination, the Legal Structure and Security of Property Rights is a continuous variable ranging between one and ten; a higher score corresponds to a better protection of private property rights. As far as we are aware, this variable has the longest time span-having been recorded every five years from 1970 until 2000 (and every year from 2001 on) - for a large number of developing economies. This makes it crucial to conduct panel data analysis. The Fraser Property Rights index is a subjective measure and expresses experts' judgments on the property rights protection for foreign investors and the business community, which may or may not coincide with the perceptions of property rights protection among citizens at large. Isaksson (2011), for example, has argued that it would be far-fetched to assume so, since it is based on surveys of a small cross-section of economic actors. The Fraser Property Rights index is not designed for such a purpose (neither are its sources, or alternative indices) and, hence, carries no information on the within-country variability of property rights protection across groups (see Isaksson 2011, and Lawson-Remer 2010). In other words, such an index does not express the inclusiveness of property rights protection (e.g., rich and poor, peasants and big corporations, men and women, diverse ethnic groups, etc.). ${ }^{6}$

This feature is particularly suited to testing the hypotheses. The paper tries to establish if the existing property rights institutions increase income inequality by favoring specific social groups in developing economies, rather than protecting everybody's capability to appropriate returns from the production factors they own. Its companion hypothesis is that the distributive effect of increasing the level of property rights protection is expected to be heterogeneous, depending on changes in the political system. In this case, the more the property rights index takes this inclusiveness into account, the less the observed parameter heterogeneity of the effect of property rights would be (with increased democratization). If we had a property rights proxy that perfectly captures property rights protection for society as a whole, perhaps we would observe no parameter heterogeneity.

As a democratization measure, we utilize the index by Vanhanen (2000), which is a continuous variable, taking values greater or equal to zero, and is computed by multiplying, and dividing by 100 , two indices (with equal weight): competition and participation. ${ }^{7}$ This index presents four properties that make it suitable for our analysis: (i) it is an objective index, hence it is not affected by analysts' explicit inclusion or individual bias toward the existence and protection of private property rights as a defining attribute of political democracy; (ii) it is continuous, thus capturing the fact that (unlike its dichotomous alternatives) political systems in developing economies are a mixture of democratic and authoritarian practices; most developing economies are also 'developing democracies', as the political transition is still unraveling; (iii) it has the useful property of taking into account citizens' participation in the democratic process (unlike its alternatives), which testifies to the real extent to which political power is equally shared and the strength of elite privileges, as the argument of our paper suggests; (iv) it adopts a minimalist definition, in line with many others, which captures the few necessary attributes of a procedural democracy.

\footnotetext{
${ }^{6}$ Details are available from the Economic Freedom of the World Reports (e.g., Gwartney and Lawson 2007).

${ }^{7}$ Competition is calculated by subtracting the percentage of votes won by the largest party from 100 (i.e., the smaller parties' share of the votes cast in parliamentary or presidential elections). If data on the distribution of votes are not available, this variable is calculated on the basis of the distribution of seats in parliament. Participation is calculated as the share of population that actually votes as a percentage of total population.
} 
Turning to the control variables, Easterly (2007) has recently suggested the use of the share of agricultural land occupied by family farms - recorded every ten years from 1858 to 1998 by Vanhanen (2005) — as a proxy of land and asset inequality. In panel regressions, its data points are too few to yield a meaningful sample size. However, we can exploit another proxy for asset inequality. Despite some data quality issues, Castelló and Doménech (2002) constructed Gini coefficients of the distribution of education for 108 countries over five-year intervals from 1960 to 2000 . Our dataset is completed with the secondary enrollment rate by Barro and Lee (2001), and some macroeconomic variables from the World Development Indicators (World Bank 2007): GDP per capita, annual inflation (consumer price index), and the ratio of the monetary aggregate M2 on GDP, capturing the level of financial development.

\section{Empirical analysis}

This section first discusses the cross-section results comparing benchmark regressions with those where the institutional parameter is allowed to vary with the measures of democratization. It then moves on to panel data results, including a discussion on their sensitivity. Finally, we evaluate the findings, also in relation to the wider literature.

\subsection{Cross-section evidence}

Table 1 reports the results. The dependent variable is the Gini coefficient measured as the average of available observations over 1991-2000. In the benchmark regression, the 19801990 average of property rights and the 1960-1990 average democracy enter in linear form, together with the initial values of other determinants of income inequality (taken in the years they are most available for developing economies). The property rights coefficient is insignificant at conventional levels. But the results change when adding the DemocratizationProperty Rights interaction term. Both the property rights coefficient, $\beta_{2}$, and the interaction term coefficient, $\beta_{3}$, are highly significant. The goodness of fit improves. A test of linear restrictions on the joint significance of $\beta_{2}$ and $\beta_{3}$ rejects the null of both being zero at $1 \%$ confidence level (also in all the remaining regressions). The third and fourth regressions verify that this is not the result of omitted variables, where the coefficients of interest are picking the effect of historical or region-specific factors. Introducing regional dummies and Easterly's (2007) wheat/sugar ratio does not alter the results. ${ }^{8}$

What is the marginal effect of property rights? Following the fourth regression, $\beta_{2}$ shows that, ceteris paribus, a one point increase in the property rights score triggers an increase income inequality Gini index of 2.166 points, when democracy scores zero. The ongoing system of property rights will increase inequality in autocratic regimes. Although empirically relevant (as six countries score zero democratization), this must be supplemented with an assessment when democracy takes values greater than zero. In Fig. 3, we report the marginal effects estimated at the observed values of the 1960-1990 democratization index in the sample. For the majority of the countries there is a positive and significant effect of property rights on inequality (significant at least at $5 \%$ level) and its value ranges, approximately, from 1.2 to 2.2 Gini points for a one-unit increase in property rights, which seems sizable

\footnotetext{
${ }^{8}$ Based on FAO data, it expresses the suitability of land to sugar versus wheat cultivation and is defined as $\ln ($ wheat $/$ sugar $)=\ln [(1+$ share of arable land suitable for wheat $) /(1+$ share of arable land suitable for sugarcane)].
} 
Table 1 Income inequality, property rights and democracy: cross-section estimates

\begin{tabular}{|c|c|c|c|c|c|}
\hline & \multicolumn{5}{|c|}{ Dependent variable: Gini coefficient, 1991-2000 (WIID) } \\
\hline & 1 & 2 & 3 & 4 & 5 \\
\hline Education 1965 & $\begin{array}{r}-0.130 \\
(0.130)\end{array}$ & $\begin{array}{r}-0.218 \\
(0.144)\end{array}$ & $\begin{array}{r}-0.229 \\
(0.154)\end{array}$ & $\begin{array}{r}-0.257 \\
(0.170)\end{array}$ & $\begin{array}{c}-0.448^{* * *} \\
(0.120)\end{array}$ \\
\hline M2/GDP 1986-1990 & $\begin{array}{r}-0.087 \\
(0.054)\end{array}$ & $\begin{array}{r}-0.061 \\
(0.056)\end{array}$ & $\begin{array}{c}0.036 \\
(0.068)\end{array}$ & $\begin{array}{c}0.058 \\
(0.070)\end{array}$ & $\begin{array}{l}0.145^{* *} \\
(0.054)\end{array}$ \\
\hline Family farms land (\%) 1988 & $\begin{array}{c}-0.192^{* * *} \\
(0.059)\end{array}$ & $\begin{array}{c}-0.173^{\text {*** }} \\
(0.060)\end{array}$ & $\begin{array}{r}-0.088 \\
(0.074)\end{array}$ & $\begin{array}{r}-0.044 \\
(0.066)\end{array}$ & $\begin{array}{r}-0.008 \\
(0.077)\end{array}$ \\
\hline $\ln (\mathrm{GDP}) 1980$ & $\begin{array}{c}3.202 \\
(2.026)\end{array}$ & $\begin{array}{c}4.249^{*} \\
(2.131)\end{array}$ & $\begin{array}{l}6.476^{* * *} \\
(2.004)\end{array}$ & $\begin{array}{l}7.695^{\text {**** }} \\
(1.379)\end{array}$ & $\begin{array}{l}7.971^{* * *} \\
(1.905)\end{array}$ \\
\hline Democratization 1960-1990 & $\begin{array}{r}-0.348^{*} \\
(0.206)\end{array}$ & $\begin{array}{c}1.198^{*} \\
(0.680)\end{array}$ & $\begin{array}{c}1.011 \\
(0.608)\end{array}$ & $\begin{array}{c}1.042 \\
(0.695)\end{array}$ & $\begin{array}{l}1.523^{*} \\
(0.825)\end{array}$ \\
\hline Property rights $1980-1990$ & $\begin{array}{c}1.335 \\
(0.831)\end{array}$ & $\begin{array}{l}3.045^{* * *} \\
(0.954)\end{array}$ & $\begin{array}{c}1.830^{*} \\
(0.973)\end{array}$ & $\begin{array}{l}2.166^{* *} \\
(0.938)\end{array}$ & $\begin{array}{l}2.571^{* *} \\
(1.174)\end{array}$ \\
\hline Prop. rights $*$ Democratization & & $\begin{array}{c}-0.312^{* *} \\
(0.121)\end{array}$ & $\begin{array}{c}-0.276^{* *} \\
(0.109)\end{array}$ & $\begin{array}{c}-0.281^{* *} \\
(0.120)\end{array}$ & $\begin{array}{c}-0.361^{* *} \\
(0.156)\end{array}$ \\
\hline MENA & & & $\begin{array}{r}-5.307 \\
(3.670)\end{array}$ & $\begin{array}{c}-8.459^{* *} \\
(3.110)\end{array}$ & $\begin{array}{c}-8.159^{* *} \\
(3.985)\end{array}$ \\
\hline Sub-Saharan Africa & & & $\begin{array}{l}9.444^{* * *} \\
(3.366)\end{array}$ & $\begin{array}{l}9.985^{\text {**** }} \\
(3.305)\end{array}$ & $\begin{array}{l}12.163^{* * *} \\
(2.993)\end{array}$ \\
\hline Latin America & & & $\begin{array}{c}5.653 \\
(4.288)\end{array}$ & $\begin{array}{c}6.541 \\
(4.570)\end{array}$ & $\begin{array}{l}11.985^{\text {*** }} \\
(3.637)\end{array}$ \\
\hline $\ln$ (wheat/sugar) & & & & $\begin{array}{r}-4.115 \\
(5.641)\end{array}$ & $\begin{array}{c}1.543 \\
(5.826)\end{array}$ \\
\hline Constant & $\begin{array}{c}31.502^{* *} \\
(14.791)\end{array}$ & $\begin{array}{c}15.464 \\
(17.420)\end{array}$ & $\begin{array}{l}-7.532 \\
(17.341)\end{array}$ & $\begin{array}{r}-20.471 \\
(12.348)\end{array}$ & $\begin{array}{r}-29.471^{*} \\
(15.851)\end{array}$ \\
\hline$F$-stat. & $9.416^{* * *}$ & $7.519^{* * *}$ & $9.456^{* * *}$ & $14.466^{* * *}$ & $9.515^{* * *}$ \\
\hline Adj. $R$-sq. & 0.338 & 0.373 & 0.520 & 0.601 & 0.685 \\
\hline Obs. & 47 & 47 & 47 & 44 & 44 \\
\hline RMSE & 6.791 & 6.608 & 5.782 & 5.391 & 5.319 \\
\hline Estimation method & OLS & OLS & OLS & OLS & IRLS \\
\hline
\end{tabular}

Notes: ${ }^{*},{ }^{* *}$ and ${ }^{* * *}$ stand for significant at 10,5 and $1 \%$ respectively, two-tailed test-heteroskedasticityrobust standard errors in parentheses. OLS specifications pass normality test of residuals (Jarque-Bera test) and Ramsey RESET test (with square and cubic $y$-hat)

(the Fraser property rights index has a standard deviation of 1.26). ${ }^{9}$ Figure 3 also shows that countries with more democratic political institutions are able to mitigate first, and then reverse the marginal effect sign from positive to negative, thus reducing inequality. A second group of countries falls within the region bounded between the two $5 \%$ confidence lines of

\footnotetext{
${ }^{9}$ Some countries which fall within this group are Sub-Saharan African economies-e.g., Zimbabwe, Congo (Rep.), Tanzania, South Africa, Kenya, Zambia - and Latin American countries, e.g., Haiti, Panama, Chile, Paraguay and Nicaragua. Asian countries in this group are Indonesia, Pakistan and Bangladesh.
} 
Marginal Effect of Property Rights on Inequality As Democracy Changes

Dependent Variable: Gini coefficient

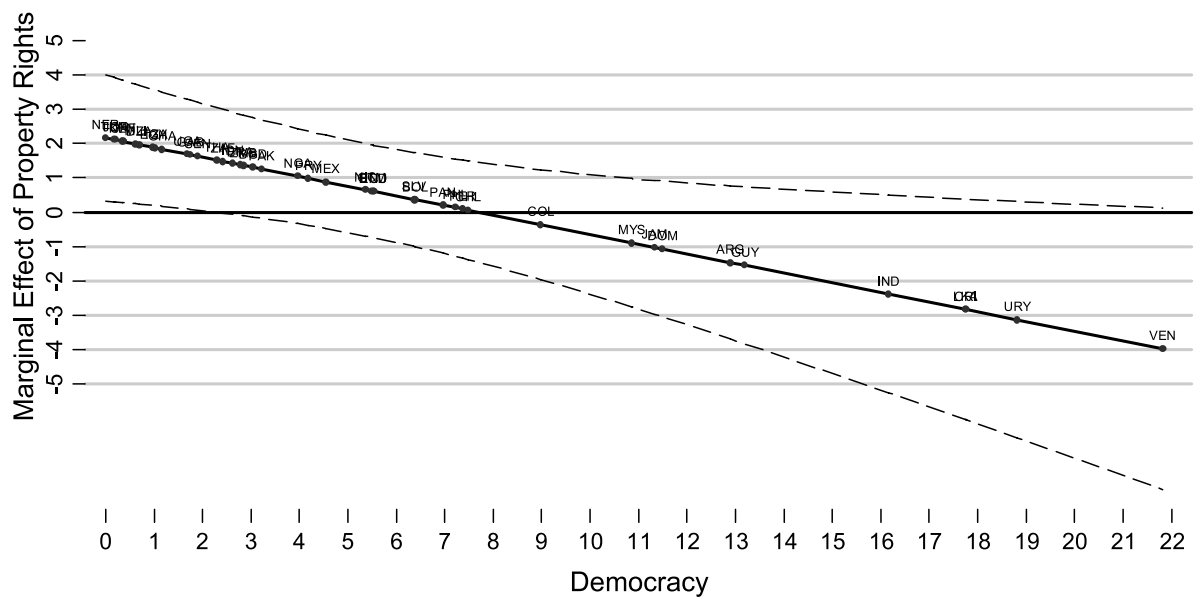

$\longrightarrow$ Marginal Effect of Property Rights
$-----95 \%$ Confidence Interval

Fig. 3 Effect of property rights on inequality at different stages of democratization

the graph, where the calculated marginal effect is statistically not different from zero. ${ }^{10} \mathrm{Fi}$ nally, only a handful countries seem to have political systems such that the partial effect of economic institutions is reversed and shows a negative sign. In this small group of countries we find India, which is an established democracy, Uruguay, Venezuela and Costa Rica also lie within this area. However, the significance of effects for such economies (with a more consolidated democracy) is marginal ( $10 \%$ level), at best.

Cross-section results are insensitive to a number of robustness checks. Do influential or outlying observations drive them? The fifth regression presents estimates using iteratively reweighted least squares (IRLS), which down-weights observations with large residuals, providing evidence in support of the generality of the results. Similarly, by excluding from the regression countries with large DFITS statistics (the threshold is $\left|\mathrm{DFITS}_{j}\right|>2 \sqrt{k / N}$ ), we conclude that influential observation does not significantly affect our estimates. Next, we have calculated DFBETA statistics to check whether influential observations affect the magnitude of the property rights coefficient, $\beta_{2}$, and the interaction term coefficient, $\beta_{3}$. Their estimates show little sensitivity once we remove from the regressions values that are above the cut-off $\mid$ DFBETA $_{j} \mid>2 \sqrt{N}$. In particular, countries that seem to be potentially influential for the property rights coefficient are the Philippines, Ghana and Jamaica; and Venezuela, for the interaction term coefficient.

\subsection{Panel data evidence}

Cross-section results suggest that countries with stronger property rights protection have higher income inequality, an effect which is larger in low-democracy environments. The

\footnotetext{
${ }^{10}$ In particular, countries scoring a democracy level approximately equal to four (out of 21.82, the maximum) are sufficiently democratic to neutralize the inequality-worsening effect of property rights.
} 
complement to this is to investigate the short-run side of the relationships under scrutiny by estimating equation (3).

The panel has an unbalanced and unequally spaced structure, spanning from 1970 to 2004. We average our series over 5-year periods (1970-1974, 1975-1979 and so on). But property rights scores, the proxy for asset inequality, and education data are originally recorded at the very beginning of every 5-year episode (1970, 1975 and so on). Table 2 presents LSDVC estimates, alongside OLS and within FE estimates (which are the 'upper' and 'lower-bound' estimates of $\varphi$, respectively), to give an appreciation of the coefficients bias and allow comparisons with the bias-adjusted estimates. In this case, $\beta_{2}$ and $\beta_{3}$ are underestimated by OLS, whereas $\varphi$ is overestimated. The opposite holds for within FE estimates. LSDVC estimates fall in-between, as expected, and confirm the nonlinear effect of property rights protection on inequality, not just in the long run (as found in the cross-section estimates) but also when looking at their changes. ${ }^{11}$

In a dynamic context, the short-run (i.e., 5-year) impact of property rights on inequality is the usual marginal effect, i.e., a function of $\beta_{2}$ and $\beta_{3}$ and democratization. This can now be distinguished from the long-run multiplier. If causal, this estimate would imply that a one-unit strengthening of private property protection increases the 'steady-state' value of inequality by a cumulative, long-run effect of $\left(\beta_{2}+\beta_{3} I_{i t}\right) /(1-\varphi)$, ceteris paribus. The bias-adjusted FE regression suggests it is 2.43 , evaluated at democracy first decile (which is zero). The corresponding effect for one standard deviation of property rights, instead, would be 3.35 Gini points. This effect is relatively large, bearing in mind that the mean of inequality in developing countries is 49.76 .

Note also that, since Vanhanen's index is zero in a nontrivial number of cases $(31.24 \%)$ over the 1960-2000 period in developing economies, $\beta_{2}$ (and its corresponding long-run effect) can have an interpretation that is theoretically, as well as empirically, relevant for the short-run impact of property rights on inequality. However, a full assessment of such effect should also look at the cases when democratization takes values greater than zero, i.e., when the moderating effect of $\beta_{3}$ begins. Based on the LSDVC estimates (third regression), Table 3 reports significance and magnitude of the effects of property rights on the Gini index evaluated at the median score of the democratization index, its 1st and 4th quartile, as well as its 1 st and top decile scores (first column).

When property rights increases by one unit, its effect on inequality when evaluated at Vanhanen's index first decile or quartile is 1.34 Gini points (2.12 points for a one standard deviation increase, i.e., 1.58 units, in a five-year timeframe), ceteris paribus. Such effect decreases, but is still positive and marginally significant, when democracy is at its median. It turns insignificant when democracy is at its 3rd quartile. Finally, when democracy is at its top decile, the effect switches sign to negative, but it is not statistically significant. It is noteworthy though as it shows that, only when countries achieve a high level of democratization, they have sufficiently representative systems to reverse the inequality-worsening

\footnotetext{
${ }^{11}$ In principle, measurement error and endogeneity might still cast doubt on the results. Measurement error, understood as the discrepancy between our institutional indicators and the 'true' concept of institutions we would like to capture, could affect both property rights and democracy measures. If the noise can be approximated by classic errors in variables assumption (measurement error is uncorrelated with the true variable we would like to observe), this is a source of attenuation bias. Therefore, it stacks the odds against our results, implying that estimates of the effect of property rights are conservative. Regarding endogeneity, one may argue that income inequality and property rights simultaneously affect each other or they could be linked over time by a feedback process (Keefer and Knack 2002, and Chong and Gradstein 2007). Although we share this concern, perhaps it is not a major drawback as we find no evidence of 2nd-order serial correlation in the residuals of any regressions above, suggesting that these effects are not driving our results.
} 
Table 2 Income inequality and property rights: panel estimates

\begin{tabular}{|c|c|c|c|c|c|}
\hline & \multicolumn{5}{|c|}{ Dependent variable: Gini coefficient (WIID) } \\
\hline & 1 & 2 & 3 & 4 & 5 \\
\hline \multirow[t]{2}{*}{$\operatorname{Gini}_{t-1}$} & $0.947^{* * *}$ & $0.282^{* * *}$ & $0.449^{* * *}$ & $0.514^{* * *}$ & $0.455^{* * *}$ \\
\hline & $(0.043)$ & $(0.137)$ & $(0.127)$ & $(0.135)$ & (0.124) \\
\hline \multirow[t]{2}{*}{ Education } & -1.076 & 0.455 & 0.257 & -1.423 & 0.127 \\
\hline & $(0.870)$ & $(1.732)$ & $(1.851)$ & $(3.077)$ & $(1.886)$ \\
\hline \multirow[t]{2}{*}{ M2/GDP } & -0.010 & 0.004 & -0.003 & -0.015 & 0.000 \\
\hline & $(0.015)$ & $(0.052)$ & $(0.039)$ & $(0.081)$ & $(0.045)$ \\
\hline \multirow[t]{2}{*}{ Asset inequality } & -0.029 & $0.230^{* *}$ & $0.197^{* *}$ & 0.158 & $0.188^{*}$ \\
\hline & $(0.039)$ & $(0.095)$ & $(0.092)$ & $(0.104)$ & $(0.098)$ \\
\hline \multirow[t]{2}{*}{ Property rights } & 0.318 & $1.409^{* *}$ & $1.340^{* *}$ & $1.422^{* *}$ & 1.518 \\
\hline & $(0.697)$ & $(0.659)$ & $(0.668)$ & $(0.674)$ & $(1.642)$ \\
\hline \multirow[t]{2}{*}{ Democratization } & 0.080 & $0.380^{* *}$ & $0.371^{*}$ & -0.140 & 0.346 \\
\hline & $(0.177)$ & $(0.144)$ & $(0.204)$ & $(0.437)$ & $(0.231)$ \\
\hline \multirow[t]{2}{*}{ Property rights $*$ Democratization } & -0.030 & $-0.084^{* * *}$ & $-0.081^{* *}$ & $-0.085^{* *}$ & $-0.084^{* *}$ \\
\hline & $(0.035)$ & $(0.030)$ & $(0.038)$ & $(0.039)$ & $(0.040)$ \\
\hline \multirow[t]{2}{*}{ Education $*$ Democratization } & & & & 0.145 & \\
\hline & & & & $(0.163)$ & \\
\hline \multirow[t]{2}{*}{$\mathrm{M} 2 / \mathrm{GDP} *$ Democratization } & & & & 0.001 & \\
\hline & & & & $(0.004)$ & \\
\hline \multirow[t]{2}{*}{ Asset inequality $*$ Democratization } & & & & 0.924 & \\
\hline & & & & $(0.572)$ & \\
\hline \multirow[t]{2}{*}{ Democratization $^{2}$} & & & & & 0.001 \\
\hline & & & & & $(0.005)$ \\
\hline \multirow[t]{2}{*}{ Property rights ${ }^{2}$} & & & & & -0.015 \\
\hline & & & & & $(0.188)$ \\
\hline \multirow[t]{2}{*}{$\ln (\mathrm{GDP})$} & $-14.301^{* *}$ & -3.385 & -7.284 & -16.125 & -7.473 \\
\hline & $(6.536)$ & (13.188) & $(14.481)$ & $(17.074)$ & $(14.697)$ \\
\hline \multirow[t]{2}{*}{$\ln (\mathrm{GDP})^{2}$} & $0.968^{* *}$ & -0.037 & 0.254 & 0.862 & 0.269 \\
\hline & $(0.461)$ & $(0.988)$ & $(0.995)$ & $(1.186)$ & (1.006) \\
\hline \multirow[t]{2}{*}{ Inflation (CPI) } & 0.035 & 0.021 & 0.020 & 0.021 & 0.021 \\
\hline & $(0.023)$ & $(0.015)$ & $(0.021)$ & $(0.022)$ & $(0.022)$ \\
\hline \multirow[t]{2}{*}{ Constant } & $54.286^{* *}$ & 40.219 & & & \\
\hline & (20.879) & $(45.325)$ & & & \\
\hline Time effects & Yes & Yes & Yes & Yes & Yes \\
\hline$F$-stat. & $70.831^{* * *}$ & $23.298^{* * *}$ & & & \\
\hline$R$-sq. & 0.891 & 0.541 & & & \\
\hline Obs. & 120 & 120 & 120 & 120 & 120 \\
\hline Countries & 42 & 42 & 42 & 42 & 42 \\
\hline Estimation method & Pooled OLS & Within FE & LSDVC & LSDVC & LSDVC \\
\hline
\end{tabular}

Notes: ${ }^{*},{ }^{* *}$, and ${ }^{* * *}$ stand for significant at 10,5 and $1 \%$ respectively, two-tailed test-FE and pooled OLS standard errors, in parentheses, are robust for arbitrary heteroskedasticity and clustering at the country level. LSDVC standard errors are calculated by bootstrapping (50 repetitions) — time dummies are jointly significant 
Table 3 Effect of property rights on inequality at different stages of democratization

\begin{tabular}{|c|c|c|c|c|c|c|}
\hline & Dependen & variable & & & & \\
\hline & 1 & 2 & 3 & 4 & 5 & 6 \\
\hline & $\begin{array}{l}\text { Gini } \\
\text { index }\end{array}$ & $\begin{array}{l}\text { 1st } \\
\text { quintile }\end{array}$ & $\begin{array}{l}\text { 5th } \\
\text { quintile }\end{array}$ & $\begin{array}{l}\text { 1st } \\
\text { decile }\end{array}$ & $\begin{array}{l}\text { 10th } \\
\text { decile }\end{array}$ & $\begin{array}{l}\text { Middle } \\
\text { class share }\end{array}$ \\
\hline Democrat. 1st decile [0] & $1.340^{* *}$ & -0.116 & $1.789^{* * *}$ & -0.005 & $2.004^{* * *}$ & $-1.535^{* * *}$ \\
\hline & $(0.668)$ & $(0.116)$ & $(0.532)$ & $(0.057)$ & $(0.589)$ & $(0.582)$ \\
\hline Democrat. 1st quartile [0] & $1.340^{* *}$ & -0.116 & $1.789^{* * *}$ & -0.005 & $2.004^{* * *}$ & $-1.535^{* * *}$ \\
\hline & $(0.668)$ & $(0.116)$ & $(0.532)$ & $(0.057)$ & $(0.589)$ & $(0.582)$ \\
\hline Democrat. median [3.16] & $1.085^{*}$ & -0.094 & $1.568^{* * *}$ & 0.001 & $1.788^{* * *}$ & $-1.356^{* * *}$ \\
\hline & $(0.579)$ & $(0.098)$ & $(0.456)$ & $(0.048)$ & $(0.506)$ & $(0.469)$ \\
\hline Democrat. 3rd quartile [12.58] & 0.324 & -0.029 & $0.910^{* * *}$ & 0.010 & $1.139^{* * *}$ & $-0.822^{* * *}$ \\
\hline & $(0.418)$ & $(0.064)$ & $(0.318)$ & $(0.031)$ & $(0.352)$ & $(0.281)$ \\
\hline Democrat. 10th decile [18.52] & -0.155 & 0.012 & 0.494 & 0.017 & $0.731^{*}$ & $-0.486^{* *}$ \\
\hline & $(0.451)$ & $(0.070)$ & $(0.351)$ & $(0.033)$ & $(0.383)$ & $(0.236)$ \\
\hline
\end{tabular}

Notes: ${ }^{*},{ }^{* *}$, and ${ }^{* * *}$ stand for significant at 10,5 and $1 \%$ respectively, two-tailed test. Estimates refer to the effect of a one point increase in the property rights score. Observed democratization scores are in square brackets. Standard errors are in parentheses

effect of property rights regimes, or at least neutralize it. For a relevant number of countries in the sample, inequality increases when property rights protection is greater, although democratization can attenuate this effect. ${ }^{12}$

The next step is to check the robustness of the results above. Firstly, is the property rights-democracy interaction the only one at work? The type of political environment could also affect the poor's access to production factors: land and physical, financial and human capital. In democracies, governments can be forced by the electoral process to design land reforms and regulate the credit market, which would thus become less concentrated. Human capital can become affordable to the have-nots, by improving the quality of education and public health care systems (e.g., Robinson 2001; Lake and Baum 2001; Baum and Lake 2003). Therefore, in democracies, the extent of education, land inequality and financial development can have a different impact than in non-democracies. The fourth regression, in Table 2, tests this hypothesis. There is no evidence that democracy has an effect through its interaction with education, financial development, and the distribution of assets. The only channel is through influencing the functioning of property rights rules, which is the only significant interaction term of the democratization index.

Another concern is that our results could mimic those in Chong and Calderón (2000), who found an inverted-U relationship between inequality and economic institutions, or those

\footnotetext{
${ }^{12}$ For completeness, we have also considered the partial effect of democratization at different levels of property rights. For instance, Bjørnskov (2010) argued, and presented evidence, that democracies in developing economies can increase inequality as they are prone to rent-seeking activities on the part of the local elite. Hence, an alternative interpretation to our interaction term could be that developing economies with stronger economic institutions could be less prone to such effects. To test this hypothesis, we have estimated magnitude and significance of the partial effect of democratization (in income shares and Gini regressions) calculated at the 10th, 25th, 50th, 75th, and 90th percentiles of the property rights index. Such estimates, which are available in the discussion paper version, show that the effect of democracy can decrease in magnitude and even change sign as economic institutions become stronger. However, there is no evidence that such effects are significant at the conventional levels.
} 
published in Chong (2004) and Tam (2008), who instead found an inverted-U relationship between inequality and democratization. To address this concern, the fifth regression, in Table 2, adds as further controls the squared terms of the Vanhanen's index and the property rights index. The key results of paper on the effect of property rights protection and its interaction with political democracy are unchanged (although collinearity inflates the standard errors of the property rights coefficient, which shows a VIF of 28.55 with its squared counterpart).

What about the sensitivity of the results to the use of alternative democratization measures? We have experimented with other objective measures: the polichotomous Xpolity index, suggested by Vreeland (2008), and the dichotomous DD index, by Cheibub et al. (2010). When using the Xpolity variable, we obtain similar results both in terms of sign and significance, while with the DD index the standard errors are too large for the coefficients to reach conventional levels of significance. Perhaps this is due to the fact that the variability of a dichotomic index may not express the nuances of democratic change that a continuous index would instead capture (the mixture of authoritarian and democratic features of developing economies).

Finally, Table 2 regressions have also been estimated when excluding, in turn, each continent from the sample. Signs stay as expected in all cases. However, when excluding Latin American and Asian countries, our coefficients of interest lose significance at conventional levels. However, the sample size drops sharply (to 64 and 86 observations, respectively). Hence, the lack of significance could result from the loss of degrees of freedom.

\subsubsection{A closer look at the distribution of income}

Here we look at the profile of inequality. Using the Gini index as a dependent variable does not uncover the mechanics behind the rise in inequality when strengthening property rights institutions in developing economies. Which classes gain? And which ones lose? The regressions in Table 4 replace the Gini index with income shares. The related marginal effects (reported in Table 3, columns 2-6) show that, in the absence of democracy, property rights institutions increase the share of income accruing to the top quintile and decile. On the contrary, the middle-class share (the sum of the three middle quintiles) decreases. These effects should be eroded when democracy increases. There is no evidence, instead, that property rights regimes affect the share of income accruing to the bottom quintile and deciles, which is suggestive of the effects of economic institutions on poverty. Taken together, these results suggest that, in the absence of political equality, the mechanism leading to an increase in inequality is one where economic institutions benefit the upper classes, impede the formation of a larger middle-class, and leave the lower classes further behind. Increases in political equality may mitigate or even block such mechanisms. Yet, such findings must be interpreted with caution. Due to the reduced availability of income shares data in the WIDER database, they are based on regressions using a substantially lower number of observations than others where the dependent variable was the Gini index.

\subsection{Discussion of results}

Panel evidence confirms the findings from cross-section results and shows that positive changes in property rights protection lead to a change in the same sign of income inequality. Moving toward a more democratic political system can counteract this effect. Together, the cross-section and panel data results show a robust empirical regularity: the effect of property rights does not result from the omission of any regional fixed effect, or historical or countryspecific factor (as well as common shocks). Nevertheless, one should not be tempted to make 
Table 4 Income inequality and property rights: LSDVC estimates by income shares

\begin{tabular}{|c|c|c|c|c|c|}
\hline & Dependent & ariable & & & \\
\hline & 1 & 2 & 3 & 4 & 5 \\
\hline & $\begin{array}{l}\text { 1st } \\
\text { quintile }\end{array}$ & $\begin{array}{l}5 \text { th } \\
\text { quintile }\end{array}$ & $\begin{array}{l}\text { 1st } \\
\text { decile }\end{array}$ & $\begin{array}{l}\text { 10th } \\
\text { decile }\end{array}$ & $\begin{array}{l}\text { Middle } \\
\text { class share }\end{array}$ \\
\hline Inequality $_{t-1}$ & 0.166 & 0.201 & $0.230^{*}$ & $0.275^{*}$ & 0.257 \\
\hline & $(0.129)$ & $(0.154)$ & $(0.128)$ & $(0.166)$ & $(0.189)$ \\
\hline Education & $-0.587^{* *}$ & 1.273 & $-0.295^{* *}$ & 0.916 & -0.583 \\
\hline & $(0.265)$ & $(1.312)$ & $(0.128)$ & (1.405) & $(1.226)$ \\
\hline M2/GDP & 0.006 & -0.029 & $0.005^{*}$ & -0.041 & 0.022 \\
\hline & $(0.006)$ & $(0.027)$ & $(0.003)$ & $(0.030)$ & $(0.029)$ \\
\hline Asset inequality & $-0.060^{* * *}$ & $0.157^{*}$ & $-0.027^{* * *}$ & 0.108 & -0.089 \\
\hline & $(0.020)$ & $(0.086)$ & $(0.008)$ & $(0.088)$ & $(0.080)$ \\
\hline Property rights & -0.116 & $1.789^{* * *}$ & -0.005 & $2.004^{* * *}$ & $-1.535^{* * *}$ \\
\hline & $(0.116)$ & $(0.532)$ & $(0.057)$ & $(0.589)$ & $(0.582)$ \\
\hline Democratization & -0.039 & $0.347^{* *}$ & -0.009 & $0.357^{*}$ & $-0.267^{*}$ \\
\hline & $(0.037)$ & $(0.169)$ & $(0.018)$ & $(0.183)$ & $(0.155)$ \\
\hline Prop. rights $*$ Democratization & 0.007 & $-0.070^{* *}$ & 0.001 & $-0.069^{* *}$ & $0.057^{*}$ \\
\hline & 0.166 & 0.201 & $0.230^{*}$ & $0.275^{*}$ & 0.257 \\
\hline $\ln (\mathrm{GDP})$ & -4.349 & 29.150 & -3.753 & 32.639 & -17.338 \\
\hline & $(5.224)$ & $(25.519)$ & $(2.513)$ & $(27.127)$ & $(21.596)$ \\
\hline $\ln (\mathrm{GDP})^{2}$ & 0.353 & -2.164 & $0.275^{*}$ & -2.279 & 1.339 \\
\hline & $(0.340)$ & (1.669) & $(0.164)$ & $(1.775)$ & $(1.384)$ \\
\hline Inflation (CPI) & -0.001 & 0.002 & -0.000 & 0.004 & -0.000 \\
\hline & $(0.003)$ & $(0.014)$ & $(0.001)$ & $(0.015)$ & $(0.009)$ \\
\hline Time effects & Yes & Yes & Yes & Yes & Yes \\
\hline Obs. & 66 & 66 & 66 & 66 & 65 \\
\hline Countries & 28 & 28 & 28 & 28 & 27 \\
\hline
\end{tabular}

Notes: ${ }^{*}, * *$, and ${ }^{* * *}$ stand for significant at 10,5 and $1 \%$ respectively, two-tailed test. Standard errors are calculated by bootstrapping ( 50 repetitions). Time dummies are jointly significant

stronger claims. Since the cross-section regressions do not control for country and time effects, the FE estimator is, in principle, an effective complement to cross section evidence but it also removes all the important variation in income inequality. In addition, the limited sample size does not allow the assessment of issues of robustness or address endogeneity, as one would want to.

Our findings confirm the intuition that institutional factors are important determinants of inequality as suggested in Bowles (2004) and Bourguignon et al. (2007). We also find support for the idea that the evolution of inequality is nonlinear and is driven by the transformation of political and economic institutions (Acemoglu and Robinson 2002; Piketty 2006). Whilst confirming that the impact of economic institutions is hump-shaped (e.g., Chong and Calderón 2000), we find its heterogeneity is due to the moderating role of democratization. Finally, our results also relate to the debate on the existence of a tradeoff between equity and economic freedom, which has found mixed evidence (Carter 2006; Scully 2002; Berggren 1999). We find there is a trade-off in developing economies, with re- 
spect to its property rights dimension. Importantly, democratization can have a moderating effect.

Our findings complement some recent research on the interaction effects of institutions on inequality. Bjørnskov (2010) presents evidence that foreign aid increases income inequality, as it benefits the richest quintile, and that such effects are higher in democracies. Chong et al. (2009), instead, find that aid has no effect in alleviating inequality or poverty, and that there is no robust evidence of such an effect in countries with lower corruption levels. Amongst the explanations considered, both papers also point to mechanisms whereby the elite appropriate aid resources through related rent-seeking activities. While in some respects this is similar to our argument, we find instead that in democratizing systems such inequality-increasing effects are smaller.

Our property rights index measures how attractive the investment climate is for foreign investors and other causal mechanisms related to the injection of foreign capital in developing economies are perhaps also consistent with our findings. Dependency theory explanations of inequality argue that the penetration of and dependence on foreign capital is expected to increase income inequality (Bornschier and Chase-Dunn 1985) as it creates a dualistic occupational structure in developing economies and because governments, motivated by the necessity of attracting and maintaining foreign investment, implement policies that decrease the power of labor and inhibit vertical mobility. In particular, our findings may echo a recent position within the dependency theory, which identifies the state's capacity to control and regulate foreign capital penetration and activities within its borders or to use tax and social policies as the moderating factor to curb the raise of inequality (Lee et al. 2007). Democracies may be better able to mobilize their populations and demand reforms and policies which attenuate the impact of foreign capital penetration on income distribution.

\section{Summary and conclusions}

This paper has considered two hypotheses. Firstly, that developing countries' economic institutions make income distribution more concentrated. Secondly, that this effect is weaker in more democratic countries. These hypotheses are based on the argument that economic institutions were historically designed to preserve the interest of the elite, but the extent of political power diffusion amongst citizens can modify their functioning.

The ensuing empirical investigation suggests a weaker effect of property rights institutions on income inequality in countries with higher levels of democratization. However, property rights protection significantly increases income inequality, suggesting that such institutions tend to grant opportunities to a minority rather than to a broad cross-section of society. The impact of democracy is channeled only through the property rights system. In fact, we find no evidence that democracy affects inequality by moderating the effect of financial development, education and asset inequality. A closer look at the distribution of income reveals that property rights increase the income of the top quintile and decile and decrease the middle-class share, while we have no evidence that property rights affect the share of the bottom quintile and decile. A limitation of our analysis is that it we are unable to assess the specific channels through which property rights institutions affect inequality. This remains speculative- - e.g., oligarchies' rent-seeking behavior and control of key markets, or labor markets depressing the labor share — and perhaps deserves further investigation.

The relationships we have identified support the idea that both political and economic rules are important for income inequality and have some interesting policy implications. While stimulating investment, property rights systems may exacerbate inequality, in the 
long-run, to socially unsustainable levels. Therefore, designing reforms aimed at strengthening investment incentives cannot ignore the distributional consequences of institutional change. In particular, the policy maker should concurrently consider aspects of political equality. The likely outcome of institutional development, with high-quality property rights institutions and consolidated democracy, could be attractive: improving the quality of political and economic institutions - property rights, in particular-could deliver both efficiency and equity.

Acknowledgements We thank the editor-in-chief and two anonymous referees for very helpful suggestions. All errors are our own.

\section{References}

Acemoglu, D. (2008). Oligarchic vs. democratic societies. Journal of the European Economic Association, $6(1), 1-44$.

Acemoglu, D., \& Robinson, J. A. (2002). The political economy of the Kuznets curve. Review of Development Economics, 62(2), 183-203.

Acemoglu, D., Johnson, S., \& Robinson, J. A. (2005). Institutions as the fundamental cause of long-run growth. In P. Aghion \& S. Durlauf (Eds.), Handbook of Economic Growth (vol. 1A, Chap. 6, pp. 385472). Amsterdam: North-Holland.

Amendola, A., Easaw, J., \& Savoia, A. (2011). Inequality in developing economies: the role of institutional development (Economics Department Discussion Paper Series No. 11/07). University of Exeter.

Anderson, T. W., \& Hsiao, C. (1982). Formulation and estimation of dynamic models using panel data. Journal of Econometrics, 18, 570-606.

Baltagi, B. H. (2008). Econometric analysis of panel data (4th ed.). Chichester: Wiley,

Barro, R. J., \& Lee, J. W. (2001). International data on educational attainment updates and implications. Oxford Economic Papers, 3, 541-563.

Baum, M. A., \& Lake, D. A. (2003). The political economy of growth: democracy and human capital. American Journal of Political Science, 47(2), 333-347.

Berggren, N. (1999). Economic freedom and equality: friends or foes? Public Choice, 100, 203-223.

Besley, T., \& Ghatak, M. (2010). Property rights and economic development. In D. Rodrik \& M. Rosenzweig (Eds.), Handbook of development economics (vol. V, Chap. 68, pp. 4525-4595). Amsterdam: NorthHolland.

Bjørnskov, C. (2010). Do elites benefit from democracy and foreign aid in developing economies? Journal of Development Economics, 92, 115-124.

Bornschier, V., \& Chase-Dunn, C. (1985). Transnational corporations and underdevelopment. New York: Praeger.

Bourguignon, F., Ferreira, F., \& Walton, M. (2007). Efficiency, equity and inequality traps: a research agenda. Journal of Economic Inequality, 5, 235-256.

Bowles, S. (2004). Institutional poverty traps. In S. Bowles, S. N. Durlauf, \& K. Hoff (Eds.), Poverty traps (Chap. 5, pp. 116-138). Princeton: Princeton University Press.

Bruno, G. S. F. (2005). Approximating the bias of the LSDV estimator for dynamic unbalanced panel data models. Economics Letters, 87, 361-366.

Bun, M. J. G., \& Kiviet, J. F. (2003). On the diminishing returns of higher order terms in asymptotic expansions of bias. Economics Letters, 79, 145-152.

Carter, J. R. (2006). An empirical note on economic freedom and income equality. Public Choice, 130, 163177.

Castelló, A., \& Doménech, R. (2002). Human capital inequality and economic growth: some new evidence. Economic Journal, 112, 187-200.

Cheibub, J. A., Gandhi, J., \& Vreeland, J. R. (2010). Democracy and dictatorship revisited. Public Choice, $143,67-101$.

Chong, A. (2004). Inequality, democracy and persistence: is there a political Kuznets Curve? Economics \& Politics, 16(2), 189-212.

Chong, A., \& Calderón, C. (2000). Institutional quality and income distribution. Economic Development and Cultural Change, 48, 761-786.

Chong, A., \& Gradstein, M. (2007). Inequality and institutions. Review of Economics and Statistics, 89(3), $454-465$. 
Chong, A., Gradstein, M., \& Calderón, C. (2009). Can foreign aid reduce income inequality and poverty? Public Choice, 140, 59-84.

Daudey, E., \& Garcia-Peñalosa, C. (2007). The personal and factor distributions of income in a cross-section of countries. Journal of Development Studies, 43(5), 812-829.

Easterly, W. (2007). Inequality does cause underdevelopment: insights from a new instrument. Journal of Development Economics, 84, 755-776.

Gradstein, M., \& Milanovic, B. (2004). Does liberté = egalité? A survey of the empirical links between democracy and inequality with some evidence on the transition economies. Journal of Economic Surveys, 18(4), 515-537.

Gwartney, J. G., \& Lawson, R. A. (2007). Economic freedom of the world: 2007 annual report. Available online at www.freetheworld.com. Accessed on 12th September 2007.

Isaksson, A.-S. (2011). Social divisions and institutions: assessing institutional parameter variation. Public Choice, 147(3-4), 331-357.

Keefer, P., \& Knack, S. (2002). Polarization, politics, and property rights: links between inequality and growth. Public Choice, 111(1-2), 127-54.

Lake, D. A., \& Baum, M. A. (2001). The invisible hand of democracy: political control and the provision of public services. Comparative Political Studies, 34(6), 587-621.

Lawson-Remer, T. (2010). Security of property rights for whom? (Mimeo). Available at SSRN: http://ssrn. com/abstract=1661310. Accessed on 10th September 2010.

Lee, C.-S., Nielsen, F., \& Alderson, A. S. (2007). Income inequality, global economy and the state. Social Forces, 86(1), 77-111.

Li, H., Squire, L., \& Zou, H. (1998). Explaining international and intertemporal variations in income inequality. Economic Journal, 108, 26-43.

Piketty, T. (2006). The Kuznets' Curve: yesterday and tomorrow. In A. Banerjee, R. Bénabou, \& D. Mookherjee (Eds.), Understanding poverty (Chap. 4, pp. 63-72). Oxford: Oxford University Press.

Robinson, J. A. (2001). Where does inequality come from? Ideas and implications for Latin America (OECD Development Centre working paper No. 188). December.

Rodrik, D. (1999). Democracies pay higher wages. The Quarterly Journal of Economics, 54(3), 707-738.

Scully, G. W. (2002). Economic freedom, government policy and the trade-off between equity and growth. Public Choice, 113, 77-96.

Tam, H. (2008). An economic or political Kuznets curve. Public Choice, 134, 367-389.

UNU-WIDER, United Nations University-World Institute for Development Economics Research (2007). World income inequality database. Available at http://www.wider.unu.edu/wiid/wiid.htm, version $2 \mathrm{~b}$. Accessed on 18th July 2007.

Vanhanen, T. (2000). A new dataset measuring democracy, 1810-1998. Journal of Peace Research, 37(2), 251-265.

Vanhanen, T. (2005). Democratization: a comparative analysis of 170 countries. Routledge. Data and documentation available at http://www.fsd.uta.fi/english/data/catalogue/FSD1216/. Accessed on 21st April 2008.

Vreeland, J. R. (2008). The effect of political regime on civil war. The Journal of Conflict Resolution, 52(3), 401-425.

World Bank (2007). World development indicators. Washington: World Bank. 